\title{
CONVERGENCE PROCESSES IN THE INCOME SITUATION OF ELDERLY HOUSEHOLDS IN THE BALTIC SEA COUNTRIES
}

\author{
Anna Jankowska ${ }^{1}, \mathrm{PhD}$ \\ ${ }^{1}$ Poznan University of Life Sciences
}

\begin{abstract}
The aim of this paper is to present diversification in the income situation of elderly households in the Baltic Sea Region countries (BSR) and factors affecting this process. For this purpose, dynamics and average annual rate of changes and the convergence rate were calculated, a regression model was constructed and cluster analysis was conducted. This study showed that despite an improved income situation in the countries of Central and Eastern Europe (CEE) and the observed convergence processes, the income situation of the elderly households in the European Union-15 (EU-15 ) is better and in the analysed years of 2005-2015 no significant changes were observed in this respect.
\end{abstract}

Key words: elderly households, income situation, convergence, regression, cluster analysis.

JEL code: D190, I310, J140

\section{Introduction}

In view of the progressing population ageing process, we may observe an increased interest in ageing not only in the medical or sociological, but also economic and financial aspects. Population ageing is a universal phenomenon. Visible changes in the population structure appeared as early as the 19th century in Europe, along with socio-economic transformations related with modernisation of European societies, experiencing a demographic transition from the expanding population stage characterised by high birth and death rates to the stationary stage, with low mortality and death rates; however, the intensity of these changes is gaining in importance. For example, the ageing process for the Polish population in the next decades will be progressing rapidly. For almost 2 million children aged up to 4 years, we have over 4 thousand centenarians, while in 2050 per 1 million 300 thousand children up to 4 years old there will be as many as 60 thousand people aged 100+ (Central Statistical Office, 2014). Demographic changes result both from the increasing life expectancy, thanks to advances in medicine and increased health awareness as well as decreased fertility rates. Quantitatively the elderly constitute an increasingly important group of consumers of goods and services with a specific and relatively high economic potential, which through its financial decisions will play an increasingly importance role on the market of goods and services.

In view of the above, population ageing and the income situation of such a population is a problem of importance, investigated using the interdisciplinary approach. Its role has extensive consequences both for employment, social security, the pension system, healthcare, as well as many other aspects of the economy. This increased importance of the elderly has become so apparent that it has led to the concept of the silver generation, as well as silver economy, to refer to the existing and growing potential of economic growth in state budget revenues and consumer income related with population ageing, taking into consideration the specific nature of needs of individuals aged 50+ (Swiecka B., 2016; the European Commission, 2015). The silver generation comprises a wide variety of individuals differing in terms of their social status, income, health, as well as the social and cultural context. It includes both wealthy, active individuals, and poor individuals with declining health. Since meeting the demand for goods and services for the ageing population will affect the level of economic growth and profitability of businesses catering to those needs, the silver economy thanks to the highly promising prospects for development is called the "golden market", which results from the effect of scale manifested in the forecasted high profitability (Swiecka B., 2016; Cornet G., 2015). 
The term "ageing population" refers to the increase in the number of the elderly at the simultaneous decrease in the number of children in the population. The definition of old age in many cases is related to retirement age, which varies both in individual countries and with time. The process of ageing is not uniform worldwide. The term "the elderly" refers to individuals aged $60+$ (according to the WHO) and 65+ (according to the UN), and those in the retirement age (according to the Statistical Office in Poland) (Szarota Z., 2010). Literature sources on the subject indicate that the primary factor determining the threshold of old age is the age, which - depending on the country and in many cases also on the sex - is over 50 years. The World Health Organisation distinguishes four stages of old age (Szarota Z., 2013):

- middle age - 45-59 years,

- young old age, starting from 60 years of age and lasting until 74 years of age,

- mature old age (75-89 years),

- late old age or longevity (as referred to by gerontologists), starting at 90 years of age and lasting until death.

According to the French strategy for the silver economy, initiated by Ministere des Affaires Sociales et de la Sante in December 2013, the ageing society may be divided into three groups: active, fragile and dependant, differing in their demand for goods and services (European Commission, 2015). The Federal Reserve System Survey of Consumer Finances divides households in terms of the age of the head of the household into older old - 70 years and over, younger old 62-69 years, middle-aged - 40-61 years and young - until 40 years old (Swiecka B., 2016 after the Federal Reserve System, 2013). The classifications presented above indicate the heterogeneity of age groups among the elderly, all differing in terms of their needs and potential.

In turn, literature sources published in English-speaking countries apply the following division of the elderly: 1) young old - individuals aged $60 / 65-74 ; 2$ ) old - aged 75-84; and 3) the oldest old aged 85 years and more. According to the UN, the conventional threshold for retirement age is 65 years. However, it needs to be remembered that old age is not only equivalent to the age of a given person expressed in years. We distinguish calendar (chronological) and biological age. The frequently observed discrepancies between the chronological and biological age result from the effect of many factors (Zalega T., 2016).

The aim of this study is on the one hand to show the diversification in the income situation of the elderly in the BSR countries and to specify factors affecting this situation. For this purpose, the forward regression model will be applied. On the other hand, changes in this situation will be investigated by calculating the average annual rate of change and verification whether convergence processes occurred in the years 2005-2015. Moreover, cluster analysis will be conducted using Ward's method to identify the effect of changes in factors modifying the income situation of the elderly households on the clustering of the analysed BSR countries. Data for analyses were collected from the EUROSTAT database to ensure their comparability.

\section{Results and Discussion}

When analysing the income situation, we need to remember that in the years 2005-2015 income of the elderly increased and these changes were considerable in some countries (Table 1 ). Net income in the households, where at least one person is aged at least 65 years increased over 2-fold in Latvia, 


\begin{tabular}{|c|c|c|c|c|c|c|c|c|c|c|c|c|c|}
\hline \multicolumn{4}{|c|}{ Dynamics } & \multicolumn{5}{|c|}{$\begin{array}{c}\text { average annual rate of change } \\
\text { and convergence of income in } \\
\text { households }\end{array}$} & \multicolumn{5}{|c|}{$\begin{array}{c}\text { in which at least one person is } \\
\text { over } 65 \text { years old in BSR } \\
\text { countries in the years } 2005- \\
2015\end{array}$} \\
\hline \multirow{2}{*}{ 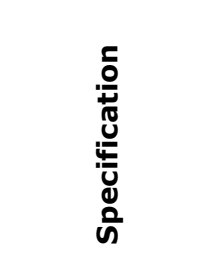 } & 옹 & $\begin{array}{l}\circ \\
\stackrel{ }{~}\end{array}$ & 옹 & 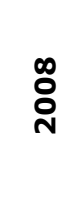 & $\begin{array}{l}\text { g } \\
\text { 오 }\end{array}$ & 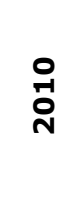 & ت্- & ㄱ. & 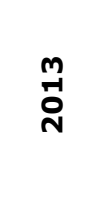 & 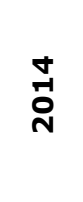 & ำ & $\frac{\text { Un }}{\text { हn }}$ & 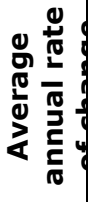 \\
\hline & \multicolumn{11}{|c|}{ thousands of Euro } & \multicolumn{2}{|c|}{$(\%)$} \\
\hline Denmark & 17.7 & 18.1 & 18.9 & 19.7 & 21.0 & 21.2 & 23.0 & 22.5 & 23.3 & 24.5 & 24.6 & 38.7 & 3.1 \\
\hline Estonia & 2.5 & 3.0 & 3.5 & 4.1 & 4.9 & 5.0 & 4.9 & 5.1 & 5.4 & 5.6 & 6.1 & $\begin{array}{r}142 . \\
8\end{array}$ & $\begin{array}{r}10 . \\
1\end{array}$ \\
\hline Finland & 14.9 & 15.8 & 16.5 & 17.3 & 18.6 & 19.8 & 20.4 & 21.3 & 21.8 & 22.7 & 23.3 & 56.1 & 4.3 \\
\hline Germany & 16.3 & 15.0 & 16.7 & 17.2 & 17.4 & 17.7 & 18.0 & 18.3 & 18.6 & 19.0 & 19.5 & 19.2 & 1.2 \\
\hline Latvia & 1.7 & 1.9 & 2.5 & 3.0 & 3.7 & 4.0 & 4.1 & 4.1 & 4.2 & 4.4 & 4.6 & $\begin{array}{r}168 . \\
5\end{array}$ & $\begin{array}{r}12 . \\
3\end{array}$ \\
\hline Lithuania & 1.9 & 2.2 & 2.6 & 3.5 & 4.1 & 4.4 & 4.0 & 4.1 & 4.5 & 4.6 & 4.6 & $\begin{array}{r}138 . \\
4\end{array}$ & $\begin{array}{r}11 . \\
2\end{array}$ \\
\hline Poland & 3.0 & 3.6 & 4.0 & 4.3 & 5.1 & 4.4 & 5.1 & 5.4 & 5.6 & 5.8 & 6.0 & $\begin{array}{r}101 . \\
9\end{array}$ & 7.9 \\
\hline Sweden & 17.4 & 18.6 & 18.7 & 19.6 & 20.3 & 19.4 & 21.9 & 23.9 & 25.8 & 27.5 & 25.7 & 47.4 & 3.7 \\
\hline $\begin{array}{l}\text { Convergenc } \\
\text { e indicator }\end{array}$ & $\begin{array}{r}0.44 \\
1\end{array}$ & $\begin{array}{r}0.41 \\
3\end{array}$ & $\begin{array}{r}0.38 \\
4\end{array}$ & $\begin{array}{r}0.35 \\
3\end{array}$ & $\begin{array}{r}0.32 \\
3\end{array}$ & $\begin{array}{r}0.32 \\
2\end{array}$ & $\begin{array}{r}0.33 \\
4\end{array}$ & $\begin{array}{r}0.33 \\
5\end{array}$ & $\begin{array}{r}0.33 \\
2\end{array}$ & $\begin{array}{r}0.33 \\
4\end{array}$ & $\begin{array}{r}0.32 \\
6\end{array}$ & $\mathbf{x}$ & $\mathbf{x}$ \\
\hline
\end{tabular}

Source: author's calculations based on Eurostat, access date: 28/03/2017.

Lithuania, Estonia and Poland. In those countries, the average annual rate of change was higher than in the others and amounted to approx. $10 \%$. The improvement of the income situation in the elderly households, most evident in the Baltic countries in the CEE group, is also confirmed by the convergence rate calculated for these years. It shows the convergence process affecting income between the Baltic states from the CEE group and the EU-15 countries. Changes in this index indicate that in the course of these years the diversification in the income situation in the analysed countries decreased by almost $1 / 3$.

In order to analyse which factors had the greatest effect on changes in the BSR states in the atrisk-of-poverty rate by household type, where at least one person is aged 65 years (the explained variable), the forward stepwise regression analysis was performed. Based on the preliminarily assumed 13 factors determining the income situation of elderly households (i.e. those, in which at least one member is over 65 years of age) such as: - inability to face unexpected financial expenses, - relative median income ratio, - part-time employment, - people living in households with very low work intensity, - the average number of adults, - overcrowding rate by household type, - average number of rooms per person by type of household, - inability to make ends meet, mean consumption expenditure, - housing cost overburden rate, - share of housing costs in disposable household income, - share of the costs of furniture and equipment, carpets and other floor coverings in the disposable income of the household, - share of rent related to occupied dwelling in disposable household income, and after considering several assumptions, e.g. that: the number of observations has to be greater or equal to the number of estimated parameters, coefficient of variation for each of the parameters has to be greater than 0.1 , - the correlations between the explaining variables need to be weaker than with the explained variable, - tolerance was greater than 0.1 , - corrected R-square has to be the greatest possible and the Variance Inflation Factor may not exceed 10. After adopting the significance of variables at the assumed 
level of $0.05 \%$, a multiple regression equation was obtained with two explaining variables: inability to make ends meet and average income per person (Table 2). A positive value of the regression coefficient shows a positive effect of such a parameter as inability to make ends meet. The value of the standard error of estimation of 3.27 (evaluation of the random deviations of the model) is interpreted as the average deviation of the percentage observed in the population from the theoretical percentage established from the model. The value of the coefficient of determination is $R^{\wedge} 2=0.95$. This means that $95 \%$ of total variation, i.e. the percentage of the elderly at risk of poverty is explained by the model. The results of the analysis of variance shows the following distribution of total variation (530.8): variation explained by the regression model 477.3 , i.e. approx. $89.9 \%$, and residual variation of 53.5 , i.e. $10.1 \%$. This shows that the fit of the model is satisfactory. In this study the variable, i.e. inability to make ends meet, has the greatest partial correlation coefficient amounting to 0.796 .

Regression values for factors determining an increased risk of poverty among the elderly households in BSR countries in $\mathbf{2 0 1 5}$

\begin{tabular}{|l|c|c|c|c|c|c|c|}
\hline \multicolumn{1}{|c|}{ Specification } & B & error B & $\mathbf{t ( 5 )}$ & $\mathbf{P}$ & Tolerance & $\mathbf{R}^{\mathbf{2}}$ & VIF \\
\hline Free term & 12.68 & 4.79 & 2.65 & 0.045680 & & & \\
\hline Inability to make ends meet & 1.30 & 0.44 & 2.94 & 0.032400 & 0.37 & 0.63 & 2.69 \\
\hline Average income per person & -0.00028 & 0.000208 & -1.33 & 0.241263 & 0.37 & 0.63 & 2.69 \\
\hline
\end{tabular}

Source: author's calculations based on Eurostat, access date: 28/03/2017

This variable alone explains $86.4 \%$ variance of the dependent variable, after the effect of other independent variables is excluded. The observation of a lack of grounds for the rejection of the zero hypothesis $(\mathrm{Ho}: \mathrm{Bi}=0)$ does not mean this hypothesis may be accepted. For this reason, a lack of proof for the significance of a variable may not be the only reason for its elimination from the regression model. The largest part, over $37 \%$ variance of variables for the inability to make ends meet and income per person, is not explained by other independent variables. The housing cost index brought the least to the model, as the statistic of the Fisher test ( $F$ ) was less than 1. However, the constructed model is useful, since the tolerance of none of the variables was below 0.1 and the Variance Inflation Factor for each variable is below 10. These variables were included in the model, as their values of the F statistic were greater than the threshold value of 1 . It may be concluded from the model that a decrease in income per person by 1 thousand Euro to the greatest extent (by $0.3 \%$ ) increases the percentage of the elderly at risk of poverty and it is followed by the inability to make ends meet. This inference seems rational and provides some insight into factors having the greatest effect on the deterioration of the income situation of the elderly in the BSR countries.

In order to evaluate the income situation of the elderly households in the BSR countries, the cluster analysis was also conducted using Ward's method both for the year 2005 and 2015. These analyses verified whether in the course of 10 years any significant changes occurred in the grouping of the investigated countries. When studying the income several factors were considered, i.e. inability to face unexpected financial expenses, relative median income ratio $(65+)$, mean income per person, at-risk-of-poverty rate, part-time employment, the percentage of people living in households with very low work intensity, the average number of adults, overcrowding rate by household type, the share of people living in under-occupied dwellings, the average number of rooms per person, inability to make ends meet and mean consumption expenditure per person. 
Considering the assumptions that correlations between variables may not be too strong, while skewness should only be positive and the coefficient of variation should exceed $10 \%$, the analysis was finally conducted on four weakly correlated variables, where the greatest value at the diagonal of the inverse matrix was 4.6. In order to ensure comparability of the results for 2005 and 2015, the same factors were considered. Finally, the analysis was conducted based on three variables: the percentage of individuals at risk of poverty or social exclusion, the share of part-time employment in total employment and mean consumption expenditure per person. This analysis provided a division of the analysed countries in terms of factors determining the income situation of households into two basic groups. One of them comprised the EU-15 countries, while the other group consists of the EU-13 countries. In the investigated 10-year period, no major shifts were observed between the analysed groups of countries. The former group of countries was composed of Denmark, Finland, Germany and Sweden, while the other comprised the CEE countries, i.e. Estonia, Lithuania, Latvia and Poland. Such a division is determined by the economic and income situation of these countries, which was also determined historically (Table 3 ).

\section{Cluster analysis using Ward's method in terms of variables characterising the income situation of the elderly households in BSR countries} for both 2005 and 2015

\begin{tabular}{|c|c|c|c|}
\hline Specification & Poverty indicator ( \%) & $\begin{array}{l}\text { Part-time employment } \\
(\%)\end{array}$ & $\begin{array}{c}\text { Mean consumption } \\
\text { expenditure } \\
\text { (Euro/person) }\end{array}$ \\
\hline \multicolumn{4}{|c|}{2005} \\
\hline \multicolumn{4}{|c|}{ I group: Denmark, Finland, Germany and Sweden } \\
\hline Mean & 10.8 & 63.6 & 20436.8 \\
\hline V ( \%) & 31.8 & 4.5 & 5.7 \\
\hline \multicolumn{4}{|c|}{ II group: Estonia, Lithuania, Latvia and Poland } \\
\hline Mean & 37.5 & 42.1 & 3479.5 \\
\hline v ( \%) & 30.4 & 26.2 & 12.8 \\
\hline \multicolumn{4}{|c|}{2015} \\
\hline \multicolumn{4}{|c|}{ I group: Denmark, Finland, Sweden and Germany } \\
\hline Mean & 7.9 & 64.7 & 21872.3 \\
\hline V ( \%) & 33.9 & 11.4 & 14.3 \\
\hline \multicolumn{4}{|c|}{ II group: Estonia, Poland, Lithuania and Latvia } \\
\hline Mean & 20.9 & 36.3 & 5173.5 \\
\hline V ( \%) & 30.5 & 18.2 & 4.9 \\
\hline
\end{tabular}

Source: author's calculations based on Eurostat, access date: 28/03/2017

It results from the cluster analysis conducted using Ward's method both for 2005 and 2015 that despite the convergence process observed in the analysed years in terms of income earned in the CEE countries in relation to the EU-15 countries, changes in the factors influencing the income situation of the elderly households are rather slow and caused no major changes in the re-grouping of the investigated BSR countries. It may be observed that in 2015 the former distinguished group of countries differed from the latter group by an over 2 -fold lower risk of poverty among the elderly households and an almost 2-fold greater percentage of the elderly employed part-time and over 4fold higher consumption expenditure per person, which still results from the better income situation of the elderly households in Western European countries. In turn, when comparing the changes in the analysed variables in 2015 in relation to 2005 we may observe that the percentage of individuals at risk of poverty among the elderly was reduced in both analysed groups of countries, 
which nevertheless was more evident in the CEE countries. In turn, the percentage of the elderly employed part time within the investigated period changed slightly in these groups. In contrast, consumption expenditure increased in both groups, in the EU-15 countries it was slightly, by as little as $7 \%$, whereas in the CEE countries it was by as much as almost $50 \%$. Such a high increase in funds spent on consumer goods in the CEE countries indicates an improved income situation of the elderly in those countries and thus confirms the occurrence of a convergence process in the income situation of the elderly households.

In the theory of consumption, economics income is treated as a major determinant indicating satisfaction of needs for a household and its individual members. It is the main measure for the level of prosperity. According to the Eurostat methodology applied in studies on income and living conditions of the population, an individual household is defined as a person living alone or a group of persons living together in the same dwelling and sharing the living expenses.

Total disposable income of a household is calculated by adding incomes earned by individual members of the household and income obtained at the household level. Disposable income of the household includes:

- Income from labour (remuneration of employees and profit from self-employment),

- Income from private investments and from real property,

- Transfers between households,

- And all social benefit transfers received in cash, including old age benefits (Wyrzykowski P., 2014).

Personal disposable income is a key economic index of consumption, which along with the other factors defines the allocation of amounts spent to meet the needs of consumers. Income obtained by consumers may thus be considered an economic foundation for each household, determining in this way the standard of living, the level of consumption and the ability to meet joint and individual needs of the household members (Zalega T., 2016, after Carroll Ch., 1997; Flavin M.A., 1981; Shefrin H.M. and Thaler R.H., 1988; Zalega, T. 2012).

The starting point for the analysis of problems related with income in the household is provided by the absolute income hypothesis proposed by J.M. Keynes, the permanent income hypothesis by M. Friedman and the life cycle theory by $A$. Ando and F. Modigliani. In contrast to the absolute income hypothesis by J.M. Keynes, assuming the dependence of consumption on current income, the permanent income hypothesis by $M$. Friedman assumes that consumption expenditure of households depends on permanent income rather than current income, the former understood as the mean lifetime income. Milton Friedman (1957) divided income earned by an individual into two parts: the permanent element connected with the potential of that individual resulting e.g. from their education, skills or profession (in theory corresponding to permanent income) and the variable (temporary) component reflecting other elements affecting income (considered to be random). The life-cycle theory by A. Ando and F. Modigliani is connected with the hypothesis of permanent income. This is equivalent to the need to accumulate savings throughout active employment in order to maintain the level of consumption when retired, i.e. when the income is reduced. This theory distinguishes two periods: professional career when people accumulate wealth, and retirement when they may take advantage of the wealth accumulated during their active employment, which in turn makes it possible to maintain a specific standard of living even when their income is lower (Zalega T., 2016 after Dirschmid W. and Glatzer E., 2004). This hypothesis assumes that the present consumption of households is not dependent on current 
income. Future plans and income forecasts are more important. As a consequence, the current consumption of an individual may be expressed as the function of resources, return on accumulated assets and age (Zalega T., 2016, after Modigliani F. and Brumberg R., 1954).

At present we may observe considerable diversification in the income situation of the elderly in the European Union. On the one hand this is caused by the economic situation of the analysed countries, the offered support system and the material situation of older citizens in the analysed countries. The income situation of the elderly is thus determined by several factors - both economic, cultural and social, as well as tradition and cultural conventions for family life in a given country.

Observed demographic changes connected mainly with the progressing population ageing lead to an increase in the importance of the segment of old age consumers on the market. A key criterion in the evaluation of market attractiveness of these segments is connected with the purchasing power of consumers, which results from their income level. It is disposable income that determines to the greatest extent the market behaviour of consumers.

The elderly contribute significantly to the socio-economic life as members of the family, employees, volunteers and consumers (the so-called silver economy). The existing stereotype of the elderly as single and poor individuals is being replaced by the image of active individuals and consumers interested in the active lifestyle, whose attitude to life is more hedonistic as well as individuals trying to satisfy their needs and those of their immediate family members. For this reason the elderly are increasingly often perceived as an important segment of the market.

We need to stress here that the elderly were brought up in the times of frequent shortages of basic products, thus their resourcefulness is much greater than that of the younger generations. It is assumed that it is the effect of the so-called financial optimism, known in financial behaviourism, as it is confirmed also by the Genworth Index, a financial reflection of the society and an indicator of how well households cope financially, according to which Poles are the greatest optimists as far as financial future is concerned. However, despite owned property, frequently inherited from generation to generation, the situation of the elderly in Poland is difficult, as indicated e.g. by the level of disability benefits and pensions, which permit them to satisfy basic needs and in many cases being so low that they do not satisfy them fully. Polish old citizens spend over $90 \%$ of their income on daily needs, including medication, which share in expenditure is much higher than in more affluent countries (the old EU) (Swiecka B., 2016). Moreover, studies show that the elderly spend a greater share of their income to pay for housing, food and healthcare, and less on clothing, transport and household equipment and fittings than the young consumers. Scientists analysed the relative weight or the share in the budget for the categories of expenses in the case of older consumers in comparison to households of individuals from other age groups. They applied a two-stage regression model, since expenditure and all other measures were determined simultaneously (Koelln K. et al., 1995). Moreover, we need to remember that the higher the household income, the greater the importance of higher rank needs. A significant role in this respect is played by the discretionary income, commonly called discretionary funds. It is this part of disposable income, which is left after meeting the basic needs, making it possible to satisfy higher needs (secondary needs). We refer here to the normal standard of living, when max. $80 \%$ income is spent on basic needs and the other $20 \%$ are discretionary funds (Zalega T., 2016). 
Finally, we need to remember that demographic changes connected with ageing of European societies will have many future economic consequences (Wyrzykowski P., 2014 after Morrow K. and Roeger W., 2012):

- the pressure on state budget expenditure related to the elderly will increase,

- the savings rate will decrease,

- changes will take place on the labour market - the number of actively employed will decrease, the retirement age limit will increase,

- the economic growth rate may decrease as a result of lower investments in the household sector.

It is forecasted that in the European Union by 2060 the share of pensions paid in the public welfare system in GDP will increase. This will mainly result from an increase in the size of this population group, since the relation of the pension paid in the public welfare system to average wages in the national economy will decrease by $19 \%$. To a considerable extent the old age dependency ratio will also increase. In 2060 the ratio will be as low as 2 individuals aged 18-64 years per 1 person aged 65 and older (in 2013 it was almost 4). This may lead to a further deterioration of the income situation for the retired population (Wyrzykowski P., 2014).

\section{Concluding remarks}

1) The analysis showed that the income situation of the elderly households is still markedly diversified between the EU-15 countries and the CEE states. However, in the course of the investigated period we may observe evident convergence processes in terms of earned income. It is also confirmed by the calculated dynamics indexes as well as the average annual rate of change.

2) At the same time the cluster analysis conducted using Ward's method showed that 10 years is an insufficiently long period for major changes in the grouping of the analysed countries in terms of the income situation in the elderly households.

3) In turn, the calculated regression model showed that among the many factors affecting the income situation of the elderly the most significant effect on the increase in the percentage of the elderly at risk of poverty may be played first of all by the obtained income, as well as the ability to satisfy basic needs, which is crucial for the future in view of providing an adequate quality and standard of living for the elderly.

\section{ACKNOWLEDGEMENTS}

This examined issues constitute a part of the project: BaltSe@nioR: Innovative solutions to support BSR enterprises in product development aimed at raising comfort and safety of seniors home living.

This work was part-financed by the European Union (European Regional Development Fund and European Neighbourhood and Partnership Instrument).

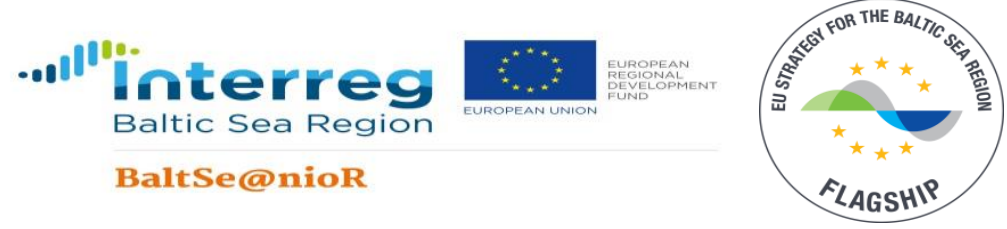




\section{Bibliography}

1. Carroll, Ch. (1992). The Buffer-Stock Theory of Saving and the Life Cycle/Permanent Income Hypothesis. Quarterly Journal of Economics, 112(1).

2. Central Statistical Office in Poland, 2014.

3. Cornet, G. (2015). Europe's 'Silver Economy': A Potential Source for Economic Growth? Gerontechnology, $13(3)$.

4. Dirschmid, W., Glatzer, E. (2004). Determinants of the Households Savings Rate in Austria. Monetary Policy \& The Economy, Q4.

5. European Commission. (2015). Growing the European Silver Economy. Background Paper. European Commission.

6. Eurostat, access date: $28 / 03 / 2017$.

7. Federal Reserve System, 2013.

8. Flavin, M.A. (1981). The Adjustment of Consumption to Changing Expectations About Future Income. The Journal of Political Economy, 89(5).

9. Friedman, M. (1957). A Theory of Consumption Function. Princeton University Press, Princeton.

10. Koelln, K., Rubin, R.M, Picard, M.S. (1995). Vulnerable elderly households: expenditures on necessities by older Americans. Social Science Quarterly. University of Texas Press, USA, 76(3), pp. 619-633.

11. Modigliani, F. and Brumberg, R. (1954). Utility Analysis and the Consumption Function: an Interpretation of Cross-Section Data. The Collected Papers of Franco Modigliani. Cambridge. The MIT Press, Massachusetts.

12. Morrow, K. Mc., Roeger, W. (1999). The economic consequences of ageing population (a comparison of the EU, US and Japan). Economic Papers. European Economy, No. 138.

13. Shefrin, H.M., Thaler, R.H. (1988). The Behavioral Life-Cycle Hypothesis. Economic Inquiry, 26.

14. Szarota, Z. (2010). Starzenie siei starosc $w$ wymiarze instytucjonalnego wsparcia (Aging and old age in terms of institutional suport). Krakow: Wydawnictwo Naukowe Uniwersytetu Pedagogicznego.

15. Szarota, Z. (2013). Spoleczno-demograficzne aspekty starzenia sie społeczenstwa (Socio-demographic aspects of population aging). In: R. Kijak and Z. Szarota, Starosc. Miedzy diagnoza a dzialaniem (Old age. Between diagnosis and action). Warszawa: Centrum Rozwoju Zasobow Ludzkich.

16. Swiecka, B. (2016). Ocena sytuacji finansowej osob starszych w Polsce ze szczegolnym uwzglednieniem zasobnosci i zadluzenia (Assessment of the financial situation of older people in Poland, with particular emphasis on wealth and indebtedness). Problemy Zarzadzania. UW, Warszawa, vol. 14, 2(59), t. 1, , pp. 118-134.

17. Wyrzykowski, P. (2014). Dochody gospodarstw domowych emerytow $w$ krajach UE (Income of retirement households in EU countries), pp. 247-257.

18. Zalega, T. (2012). Konsumpcja. Determinanty, teorie i modele (Consumption. Determinants, theories and models). PWE, Warszawa.

19. Zalega, T. (2016). Incomes and Savings of Polish Seniors in View of Research Outcomes. Problemy Zarzadzania, vol. 14, 2(59), t. 1, pp. 135-155. 